\title{
Characterization of ambient aerosols in Northern Thailand and their probable sources
}

\author{
${ }^{1 *}$ N. Tippayawong, ${ }^{2}$ P. Pengchai and ${ }^{1}$ A. Lee \\ ${ }^{1}$ Department of Mechanical Engineering, Faculty of Engineering, Chiang Mai University, Thailand \\ ${ }^{2}$ Department of Environmental Engineering, Faculty of Engineering, Chiang Mai University, Thailand \\ Received 18 August 2006; revised 5 September 2006; accepted 10 September 2006; available online 1 October 2006
}

\begin{abstract}
The present study examines variation of ambient aerosol mass and number concentrations in Chiang Mai, Thailand during winter. Aerosol particle samples were collected and measured at four different sites, representative of urban, industrial, residential and rural areas during daytime between December 2003 and January 2004. Average 10 h particulate matter (PM) mass concentrations were found to be in the range of 75-290 ì g/m³ , with average value of 149 $\pm 45 \mathrm{i} \mathrm{g} / \mathrm{m}^{3}$. Urban and industrial areas appeared to have higher PM loading than residential and rural areas. Number concentration and size distribution of particles in the range of 0.3-10.0 ì m did not exhibit any marked variation between sites. Relatively stable number concentrations were reported. Temporal variation of number concentrations was not clearly significant. No short term peak observed during rush hours. During sampling period, the average number concentration for 0.3-0.5, 0.5-1.0, 1.0-5.0 and 5.0-10.0 ì m were $6.60 \times 10^{6}, 1.18 \times 10^{6}, 2.11 \times 10^{5}$ and $1.12 \times$ $10^{4} / \mathrm{m}^{3}$, respectively. Particles with diameter smaller than $1.0 \mathrm{ì} \mathrm{m}$ accounted for over $90 \%$ of the total number concentration. Concentrations of major metals were determined by atomic absorption spectrophotometer $(\mathrm{Pb}, \mathrm{Fe}, \mathrm{Al}$, $\mathrm{Si}, \mathrm{Cr}, \mathrm{Cd}, \mathrm{Ni}, \mathrm{Zn}$ ) and flame photometer (K, Na and $\mathrm{Ca}$ ). Data obtained were used to identify probable sources via a multivariate analysis. $\mathrm{Si}, \mathrm{Na}, \mathrm{Fe}, \mathrm{Ca}, \mathrm{Al}$ and $\mathrm{K}$ were the six dominant elements in the airborne PM. Principle component analysis was carried out and major sources of airborne PM in Chiang Mai were determined, namely, (1) long distance sources such as sea spray, earth soil and industrial combustion, (2) short-distance sources such as crustal re-suspension, vehicular related emissions and vegetation burning, and (3) the unknown distance sources with low influence of traffic emissions.
\end{abstract}

Key words: Air pollution, aerosol, number concentration, elements, principle component analysis

\section{INTRODUCTION}

Ambient aerosol is a suspension of a complex mixture of liquid and solid particles in the air that vary greatly in size, composition and concentration, depending on the diverse sources generating the particles, atmospheric processes and factors such as geographic location, season, day and time of day. Particulate air pollution was one of the pollutants demonstrated to have serious short and long-term health effects, even at current low ambient levels because it can be absorbed into human lung tissue during breathing. Evidence exists to suggest that short-term changes in mortality, hospital admissions, lung function and symptoms are associated with airborne particulate matter (PM) levels, and there is evidence to suggest that long-term prevalence of symptoms and mortality from respiratory

*Corresponding author, Email: nakorn@dome.eng.cmu.ac.th Tel.: +66 5394 4146; Fax: +66 53944145 diseases is associated with ambient PM levels (Harrison, 1996). Numerous epidemiological studies (e.g. Committee on Medical Effects of Air Pollution, 1998, Pope, et al., 1995, Health Effects Institute, 2002) have reported associations between increases in exposure to PM and increases in morbidity and mortality, especially among those people with respiratory or cardiovascular disease. In view of air quality assessment, among the most important parameters of particulate matter are the mass concentration and the size distribution with little attention paid for the number loading. Air quality standards have been introduced which are mass-based and have a size related aspect to measurement, concentrating on $\mathrm{PM}_{10}$ (particles passing through a size selective inlet with a $50 \%$ efficiency cut-off at 10 $\mu \mathrm{m}$ aerodynamic diameter). Coarse fraction usually 
remains in upper airways but finer fraction like $\mathrm{PM}_{1}$ is able to penetrate deep into the human respiratory system (Hinds, 1999). Current ambient levels of particulate matter in Thailand are on average lower than the air quality standards, as reported by the Thailand's Pollution Control Department from a large number of their monitoring stations, however, occasional episodes of locally high concentration of $\mathrm{PM}_{10}$ particularly in highly polluted areas may occur in cities like Bangkok or Chiang Mai. In addition, even with concentration levels below these limits, a small percentage of people may experience adverse health effects because of individual susceptibility, a preexisting medical conditions and/or hypersensitivity (allergy). A Bangkok study (Ostro, et al., 1999) estimated that a $10 \mu \mathrm{g} / \mathrm{m}^{3}$ change in daily $\mathrm{PM}_{10}$ is associated with a 1-2\% increase in natural mortality, a $1-2 \%$ increase in cardiovascular mortality, and a 3-6\% increase in respiratory mortality. Apart from mass loading, number concentration appears to be a significant alternative/supplementary indicator for air quality assessment (Gomiscek, et al., 2004, Kreyling, et al., 2003, Harrison, et al., 1999, Trier, 1997). Asian studies that have examined PM number concentration are rare. Monkkonen, et al. (2004) reported their investigation on behavior of $\mathrm{PM}_{10}$ mass and number concentration in Delhi and found a good relationship between number and mass loading up to $300 \mu \mathrm{g} / \mathrm{m}^{3}$. Sharma, et al. (2003) measured number concentration of aerosol during summer in India and found that aerosol number concentration was high and were influenced by meteorological parameters. Laakso, et al. (2006) discussed and compared PM measurements between two Asian megacities, New Delhi and Beijing. Submicron aerosol particles were shown to be high in both cities but detailed structure of their number size distribution was different. Other studies that were carried out included Korea (Chun, et al., 2001) and China (Cheng, et al., 2005) but only during dust storm. Asian data on PM number monitoring are still scarce. For the effective management of the air quality, it is very important to identify the sources of ambient aerosol. Two dominant approaches to the PM source apportionment are the chemical mass balances (CMB) and multivariate methods (Henry, et al., 1984). It is generally accepted that the multivariate methods are best when identifying and characterizing the effects of unidentified sources while the CMB methods are best when the sources and their major characteristics are known (Gordon, 1988, Baek, et al., 1997). The multivariate analysis has been used widely in a number of Asian cities, including Bangkok, Hong Kong, Ho Chi Minh City, Delhi and Pohang (Chueinta, et al., 2000, Fung and Wong, 1995, Hien, et al., 2001, Balachandran, et al., 2000, Baek, et al., 1997). Chiang Mai is one of the major cities in Thailand. The city accommodates government offices, shopping complexes, medical, agricultural and educational institutions, industrial units and residential areas. Growing urbanization, traffic volume, commercial and industrial activities have resulted in increased concentrations of airborne particulate matter and other gaseous pollutants. This means that air quality in the critical areas and other less polluted areas in Chiang Mai remains bad, shows little signs of improving, and is becoming a major problem in Chiang Mai. There are only two monitoring stations in Chiang Mai set up by the Pollution Control Department where mass measurements are generally documented. A recent Chiang Mai aerosol study by Vinitketkumnuan, et al. (2002) also reported a mass based result in limited number of locations. Data investigating other physical parameters of ambient aerosol that are now becoming of interest (size, number) is rare and even less data exist regarding the chemical composition across Chiang Mai. The objectives of the present study are to: (i) determine spatial Chiang Mai PM mass and sizeresolved number distribution and (ii) determine the elemental composition and identify probable sources of PM in Chiang Mai.

\section{MATERIALS AND METHODS}

\section{Study areas-Chiang Mai, Thailand}

Thailand is located in the middle of Southeast Asia, neighboring Myanmar, Laos, Cambodia and Malaysia. The climate of Thailand is characterized by high temperature and humidity. Meteorologically, the year of Thailand can be divided into three seasons, cool (October-February), hot (March- May) and rainy (JuneSeptember). Chiang Mai $\left(17^{\circ} 15^{\prime} \mathrm{N}, 102^{\circ} 85^{\prime} \mathrm{E}\right)$, the chosen study area, is the second largest city in Thailand. It is situated $700 \mathrm{~km}$ from Bangkok in the upper north region of the country. Chiang Mai is situated in the Ping River valley near the foothills of Suthep Mountains at $750 \mathrm{~m}$ above sea level. It is surrounded by mountain range in the northern, eastern and western parts of the province. Average meteorological conditions in Chiang Mai at different 
seasons are shown in Fig 1. The usual temperature variation was $15-35^{\circ} \mathrm{C}$. Moderately higher temperatures were observed in the afternoon. The average wind velocity was about $2.0 \mathrm{~m} / \mathrm{s}$. The city is a major center of economic growth as well as a regional trade, public administration, education, communication and transportation hub. Government offices, shopping complexes, medical, agricultural and educational institutions, industrial units, commercial and residential areas are closed and sometimes mixed together. The city has population of about 400,000 with about three million visitors per year. As a result of growing population and economic prowess of Chiang Mai, the number of vehicles on roadways jumped from around 400,000 vehicles in 1993 to nearly 550,000 in 2000. The study areas cover the Municipality of Chiang Mai and adjoining areas with average population density of about 4300 people per $\mathrm{km}^{2}$. There are four sampling locations, chosen to reflect different influences from industrial, commercial and residential parts of the city. The area and location are depicted in Fig. 2. Site No. 1 is located outdoor on the balcony of the second floor of the Mechanical Engineering building, Faculty of Engineering, Chiang Mai University. This site is on the university campus and is about $4 \mathrm{~km}$ away from the downtown market area. It has low vehicular traffic with some residential housing that is surrounded mainly by student halls of residence. Site No. 2 is located on the balcony of the second floor of a commercial shop in an area called Ta Pae, which was close to the busy main street. Ta Pae is situated in the middle of the city area and is influenced by local traffic congestion, nearby construction sites, and street vendors. Site No. 3 is located on the third floor of Faculty of Agricultural Industry and Food Engineering building, Maejo University, about $15 \mathrm{~km}$ away from the city center. Site no. 4 is located on the ground in an outdoor patio of a residential home near Sankampaeng area which is near to a major highway and industrial areas.

\section{PM sampling}

Total suspended particulate matter (TSP) samples were collected by a low volume air sampler with flow rate of about $100 \mathrm{~L} / \mathrm{min}$. The low volume sampler was custom-designed and constructed by a team of engineers in the Department. It consists of a suction pump, a calibrated air flowmeter, a filter holder, a timer and accessories. Samplers were operated continuously during the daytime (0800 am-1800 pm). At each sampling site, new collection was performed everyday for four consecutive days of the same week, including three midweek days and one weekend day. Subsequently, the sampler was transported to successive sampling sites. Sampling campaign was carried out for one week per site between December 2003 and January 2004. Measurements were performed during the months of cool and dry season (December and January) when highest particulate matter concentrations were reported (Vinitketkumnuen, et al., 2002). The samplers were equipped with stainless steel filter holder (Gelman no. 2210) that supports a glass fiber filter (Whatman EPM 2000, $47 \mathrm{~mm}$ diameter) applying an average sampled air volume of $45 \mathrm{~m}^{3}$. Sampling was performed at about $1 \mathrm{~m}$ above the setup floor. Field blanks were determined for each sampling site and used to set limit of detection in the calculation procedure. The loaded filters were carefully removed from the holder and stored in clean Whatman Petri dishes and kept under controlled humidity and temperature during sampling period to minimize losses due to volatilization and evaporation. All those filters were weighed before and after sampling with a sensitive balance (precision $100 \mu \mathrm{g}$ ) after stabilizing in controlled humidity $(40 \%)$ and temperature $\left(25^{\circ} \mathrm{C}\right)$. A total of 64 samples were collected. Several samples were contaminated by rains and had to be discarded. Only 56 samples were available and kept between four to eight weeks prior to elemental analysis. After the sampling campaign, all samples were transported to Department of Industrial Chemistry, Chiang Mai University for elemental analysis.

\section{Number concentration}

An optical particle counter (Met One model GT-521) was used to measure the particle number concentrations. Measurement with the optical instrument was set to operate between $0800 \mathrm{am}-1800 \mathrm{pm}$ each day at each sampling site, for four consecutive days of the same week in the months of December 2003 and January 2004. A total of 32 days worth of data was obtained. The unit is small and portable with self contained power supply. The LCD display allows viewing of two discrete particle-counting channels in real time simultaneously. The particle counter has a calibrated flow rate of 2.83 $\mathrm{L} / \mathrm{min}$, which is verified to $\pm 5 \%$ accuracy. The sampling time is typically 60 seconds for all cases with logging interval of about $10 \mathrm{~min}$. The particle counter comes with an isokinetic probe that attaches to the inlet nozzle with a short piece of Tygon tubing. Isokinetic sampling 
is achieved when the probe inlet is pointed into the direction of flow and when the mean flow velocity into the inlet matches the mean flow velocity of the air at the location. The isokinetic probe helps reduce count errors related to the sample flow velocity and the aerodynamics of small particles and thus avoids using the corrections for anisokinetic conditions. The optical particle counter was operated in the dynamic range of $0.3-10 \mu \mathrm{m}$. Number concentrations were classified into four size bins, namely $0.3-0.5,0.5-1.0,1.0-5.0$ and 5.0-10 $\mu \mathrm{m}$. The data were obtained every 10 minutes and were automatically transferred to a computer through a data acquisition and process control software.

\section{Elemental analysis}

The concentrations of 11 metals in collected samples were determined by atomic absorption spectroscopy (Al, $\mathrm{Si}, \mathrm{Fe}, \mathrm{Pb}, \mathrm{Zn}, \mathrm{Cd}, \mathrm{Cr}$ and $\mathrm{Ni}$ ) and by flame photometer (Ca, Na and K). To obtain sufficient extractable PM samples, filter samples collected over a period of about two weeks were pooled together to avoid amount near minimum detectable limit of the instrument. The sample (including loaded and blank filters) was directly heated in crucible until all carbonaceous matter was removed. The ash was then allowed to cool down, and later transferred to a flask. The ash was treated with $10 \mathrm{~mL}$ of concentrated $\mathrm{HNO}_{3}$ and $30 \mathrm{~mL}$ of concentrated $\mathrm{HCl}$. All the reagents used were of analytical grade. The mixture was digested at $60{ }^{\circ} \mathrm{C}$ for at least 2-3 h. until the mixture appeared to have no residue. Digested samples were filtered and their volume adjusted to $100 \mathrm{ml}$ by adding solution of $1.0 \% \mathrm{HNO}_{3}$ in deionized double distilled water. High purity of standard stock solutions of $1000 \mathrm{ppm}(\mathrm{mg} / \mathrm{L})$ of elements was prepared from different metals. The atomic absorption determinations were measured by the Perkin-Elmer Corporation A. A. Analyst 100 instrument and all data were sampled and processed automatically via a personal computer using AA Win/Lab software. The spectrometer was operated in the absorption mode (absorbance readings), using at least three standard

Table 1: Ten hour averaged particle concentrations in Chiang Mai air

\begin{tabular}{lcc}
\hline Sampling site & \multicolumn{2}{c}{ PM concentrations $\left(\mu \mathrm{g} / \mathrm{m}^{3}\right)$} \\
\cline { 2 - 3 } & Mean $\pm \mathrm{SD}$ & Range \\
\hline Chiang Mai University & $143 \pm 35$ & $85-255$ \\
Ta Pae & $248 \pm 57$ & $179-453$ \\
Maejo & $102 \pm 31$ & $71-257$ \\
Sankampaeng & $147 \pm 25$ & $113-254$ \\
\hline
\end{tabular}

solutions for calibration. For each element determination, the recommended wavelengths were set and burner position as well as flame conditions $\left(\mathrm{C}_{2} \mathrm{H}_{2}\right.$, air, $\mathrm{N}_{2} \mathrm{O}$ ) were optimized by a standard solution. Deionized water was atomized after each reading of standard or sample. Values obtained from the field blank filters were used for adjustment and correction of data from loaded filters.

\section{Statistical analysis}

Principle component analysis (PCA) was applied to the data of metals concentrations using Kaiser normalization and Varimax rotated method in SPSS statistical software packages (SPSS Inc, USA). In order to check the stability of the result, the principal components were re-extracted one at a time after any element of very low concentration in most samples was removed from the dataset. Extracted principle components, which their combination could explain $>80 \%$ of the total data variance, were obtained as the possible sources of the PM collected in this study. Based on the matrix of principle component loading for each element, the types of those sources were determined.

\section{RESULTS}

\section{Particle concentrations}

The arithmetic mean and standard deviations as well as ranges of the $10 \mathrm{~h}$ TSP loadings measured at the four locations in Chiang Mai are shown in Table 1. In each location, four day samplings were averaged, including three midweek days and one weekend day. In this work, sampling from weekdays and weekends were not differentiated but averaged to represent each site's data. All sampling locations exhibited relatively moderate concentrations, ranging from $75-263 \mu \mathrm{g} / \mathrm{m}^{3}$. In comparison with some large cities located in Asia, the PM concentration measured in Chiang Mai is not very high. For example, average total suspended PM concentrations in Seoul, Hong Kong, Bangkok, Jarkarta, Ho Chi Minh City, and Karachi were 153, 78, 127, 211, 74 and $668 \mu \mathrm{g} / \mathrm{m}^{3}$, respectively (Panther, et al., 1999, Hien, et al., 2001, Parekh, et al., 2001). It should be pointed out here that the particle mass concentrations from this study were $10 \mathrm{~h}$ daytime average. The values are expected to be higher than $24 \mathrm{~h}$ average values since PM loading at night is relatively lower than during the day. 
Table 2: Varimax rotated factor loading matrix for elemental composition of aerosol particle combined from four sites across Chiang Mai

\begin{tabular}{lccc}
\hline Parameter & Factor 1 & Factor 2 & Factor 3 \\
\hline $\mathrm{Al}$ & 0.795 & & \\
$\mathrm{Cr}$ & & & 0.862 \\
$\mathrm{Fe}$ & & 0.856 & \\
$\mathrm{Ni}$ & 0.856 & & \\
$\mathrm{~Pb}$ & & 0.830 & \\
$\mathrm{Si}$ & & & 0.879 \\
$\mathrm{Zn}$ & & & -0.830 \\
$\mathrm{Ca}$ & 0.721 & & \\
$\mathrm{Na}$ & 0.758 & & \\
$\mathrm{~K}$ & & 0.720 & \\
\% variance & 30.6 & 27.6 & 25.7 \\
$\mathrm{Cumulative}$ & 30.6 & 58.2 & 83.9 \\
variance & & & \\
\hline
\end{tabular}

Also, measurements were performed during winter months when highest TSP concentrations were expected to occur. Similar PM mass loading was seen with those reported by Vinitketkumnuen, et al. (2002), even through there were occasionally light rains during the sampling period. The concentrations within the inner city and near industrial site were higher than those at residential and rural sites. Despite the fact that the number of samplings per site and month was not large, the overall trend clearly indicated that the highest TSP concentrations occurred during winter. Chiang Mai is surrounded by mountain ranges, and given the generally lower air movement in the winter than that in the summer, fine aerosol particle emissions from open burning and other local sources can accumulate in a smaller mixing volume over the city. Nonetheless, the values from this study were markedly lower than the values $\left(310-886 \mu \mathrm{g} / \mathrm{m}^{3}\right)$ reported for roadside PM in Chiang Mai by Matsushita et al. (1998).
Even though comparison of urban PM level is not quite straight forward because the concentrations can be site specific, a similar trend was observed for different sampling sites in Chiang Mai. This may be expected because the farthest distance between any two sites is only about $15 \mathrm{~km}$ apart. Fig. 3 displays the variation of the one-hour averages of PM size-separated number concentrations observed during daytime for all locations. Particle number concentration has a high value in morning, decreases slightly till around noon, and gradually stabilizes and becomes almost constant towards evening, similar to that reported by Monkkonen, et al. (2004). The temporal variation observed was not in accordance with variation in Chiang Mai traffic pattern and volumes. The measurements did not appear to capture the rush hours in the morning and the late afternoon. This was not anticipated because the city has a great number of registered motorcycles (more than one million) which are a popular means of transportation and used extensively by students, tourists and dwellers. Traffic emissions or nearby activities such as floor sweeping did not seem to greatly influence particle number. A great majority of particle number generated from vehicular engines must be smaller than lower bound of the current optical counter $(<0.3 \mu \mathrm{m})$, as reported by Lighty, et al. (2000). The average number concentration for particle with diameter of $0.3-0.5,0.5-1.0,1.0-5.0$ and $5.0-10.0 \mu \mathrm{m}$ were $6.60 \times 10^{6}, 1.18 \times 10^{6}, 2.11 \times 10^{5}$ and $1.12 \times 10^{4} \mathrm{~m}^{-3}$, respectively. All sites appeared to have similar order of magnitude of number concentrations for each size range.

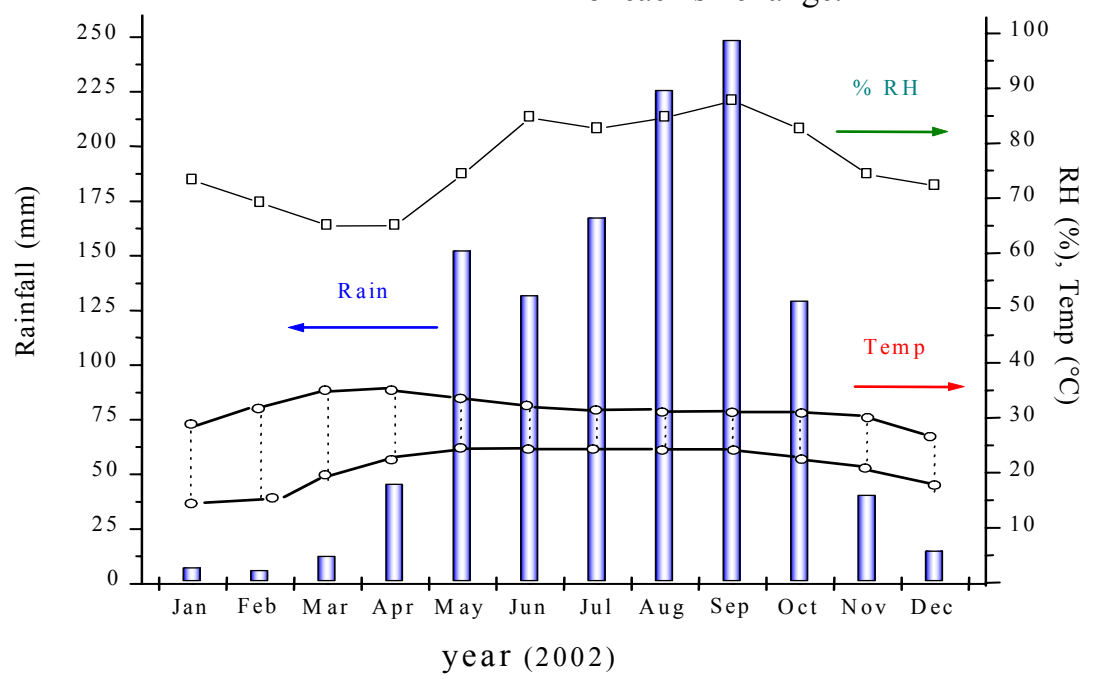

Fig. 1: Meteorological conditions in Chiang Mai, Thailand obtained from a pollution control department monitoring station 


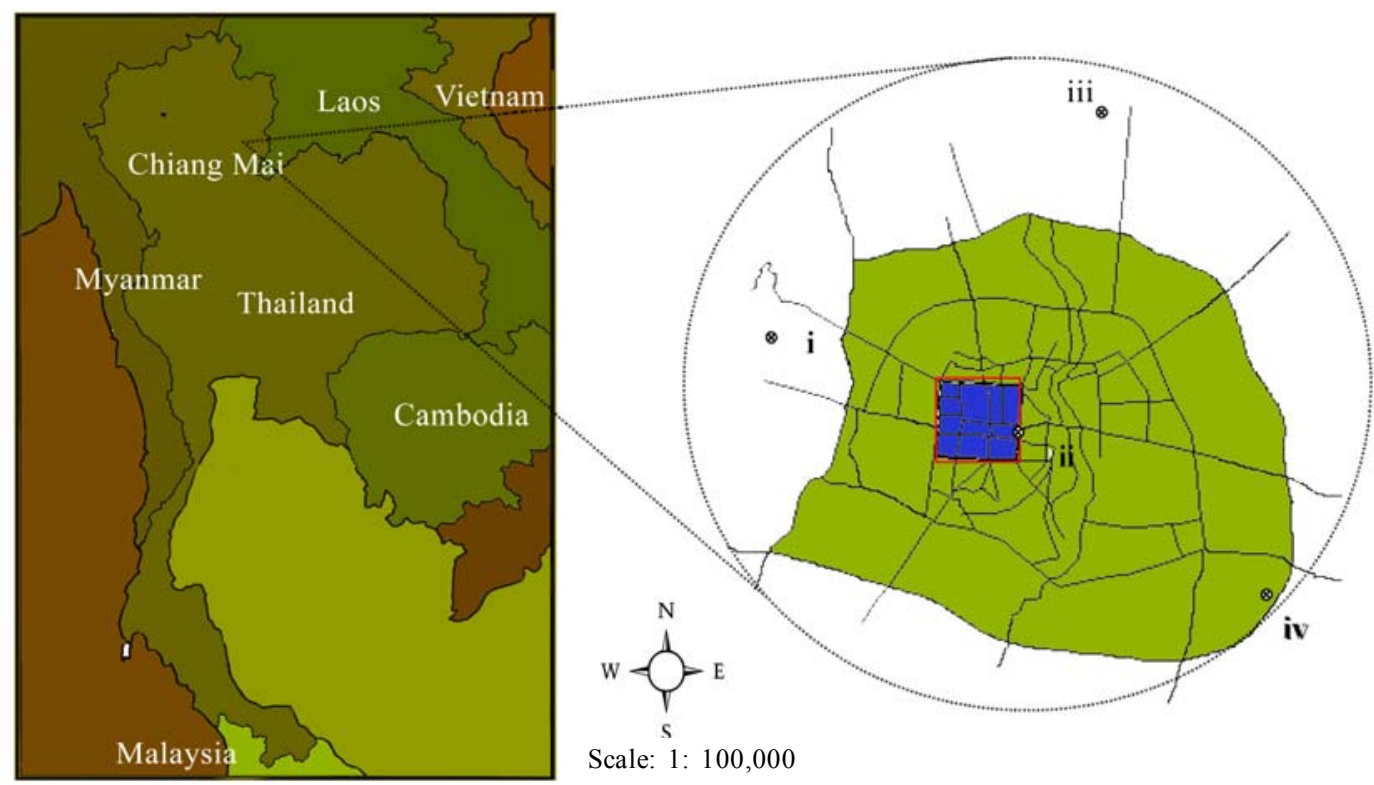

Fig. 2: Locations of air sampling stations in Chiang Mai, Thailand, (i) Chiang Mai University, (ii) Ta Pae, (iii) Maejo and (iv) Sankampaeng

Busy commercial and industrial sites did not seem to exhibit significantly higher number concentration than residential and rural sites. For smallest particles in the range of $0.3-0.5 \mu \mathrm{m}$, number concentrations were slightly changed during daytime. Larger variation was observed for particles in the range of $0.5-1.0 \mu \mathrm{m}$ and 1.0-5.0 $\mu \mathrm{m}$. They were found to show small fluctuations during the time, with decreasing trend from the morning to evening. It is implied that large particles were likely more affected by local sources such as construction or motorways. For supermicron particles (5.0-10.0 $\mu \mathrm{m})$, no distinct trend was observed. They stayed relative constant with no sudden spike. A marginal rise in concentration may be attributed to re-suspension of aggregates from construction dusts or wind blown road dust that may become unsettled by the traffic movement. Comparison of size resolved number concentration for each sampling site is shown in Fig. 4. The size distributions are represented in a log-log plot. For absolute values, it was revealed that PM number concentration in busy commercial site ( $\mathrm{Ta} \mathrm{Pae}$ ) was higher than from rural and residential sites (Chiang Mai University and Maejo). The difference grew larger for coarser particle size range. As for all sampling sites, particles with diameter less than $1.0 \mu \mathrm{m}$ accounted for over $90 \%$ of the total number concentration and they were in similar order of magnitude. With the measurement technique used, Chiang Mai ambient aerosol showed the size spectrum between 0.3 and 10 $\mu \mathrm{m}$. It is worthwhile to note that smaller particle sizes ( 0.05 to $0.3 \mu \mathrm{m})$ where largest numbers might appear have not been reported. This is evident in Fig. 4 where size distribution curves indicated a progressive increase in particle number with decreasing size. High level of fine PM concentrations in Chiang Mai, containing primary particles from combustion sources and secondary particles from gas to particle conversion, may be caused by vehicle exhaust emissions and open biomass burning. Other sources of coarser particles may come from industrial processes or construction activities.

\section{Particle elemental composition}

Total concentrations of ten metals in PM samples from each sampling site are plotted in Fig. 5. The findings showed that elemental concentration varied little between sites. Soil and road dust and construction industry related elements $(\mathrm{Al}, \mathrm{Ca}, \mathrm{Si}, \mathrm{Fe})$ appear to have a high concentration and were dominant elements in TSP. It should be noted that $\mathrm{Al}$ and $\mathrm{Ca}$ were in similar magnitude to those found in Bangkok study (Chueinta, et al., 2000). Cd was removed from the data set due to its very low content in every PM samples. High concentration of the $\mathrm{K}$ was observed. It was suggested 

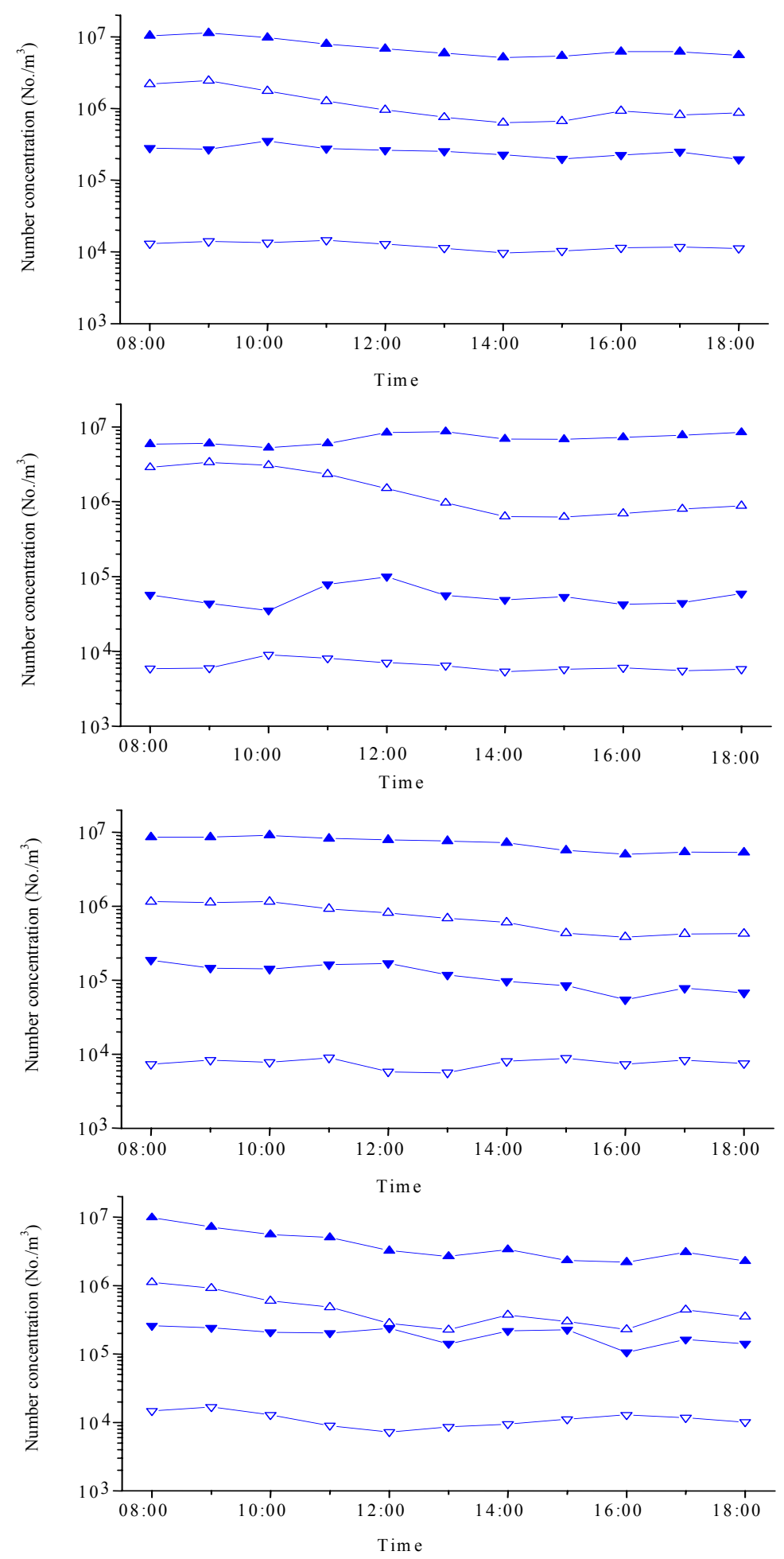

Fig. 3. Variation of PM size-resolved number concentrations in Chiang Mai ambient air for particle size: 0.3-0.5 $\mu \mathrm{m}(\mathbf{\Delta}), 0.5-1.0 \mu \mathrm{m}(\triangle), 1.0-5.0 \mu \mathrm{m}(\boldsymbol{\nabla})$, and 5.0-10.0 $\mu \mathrm{m}(\nabla)$ 
N. Tippayawong, et al.

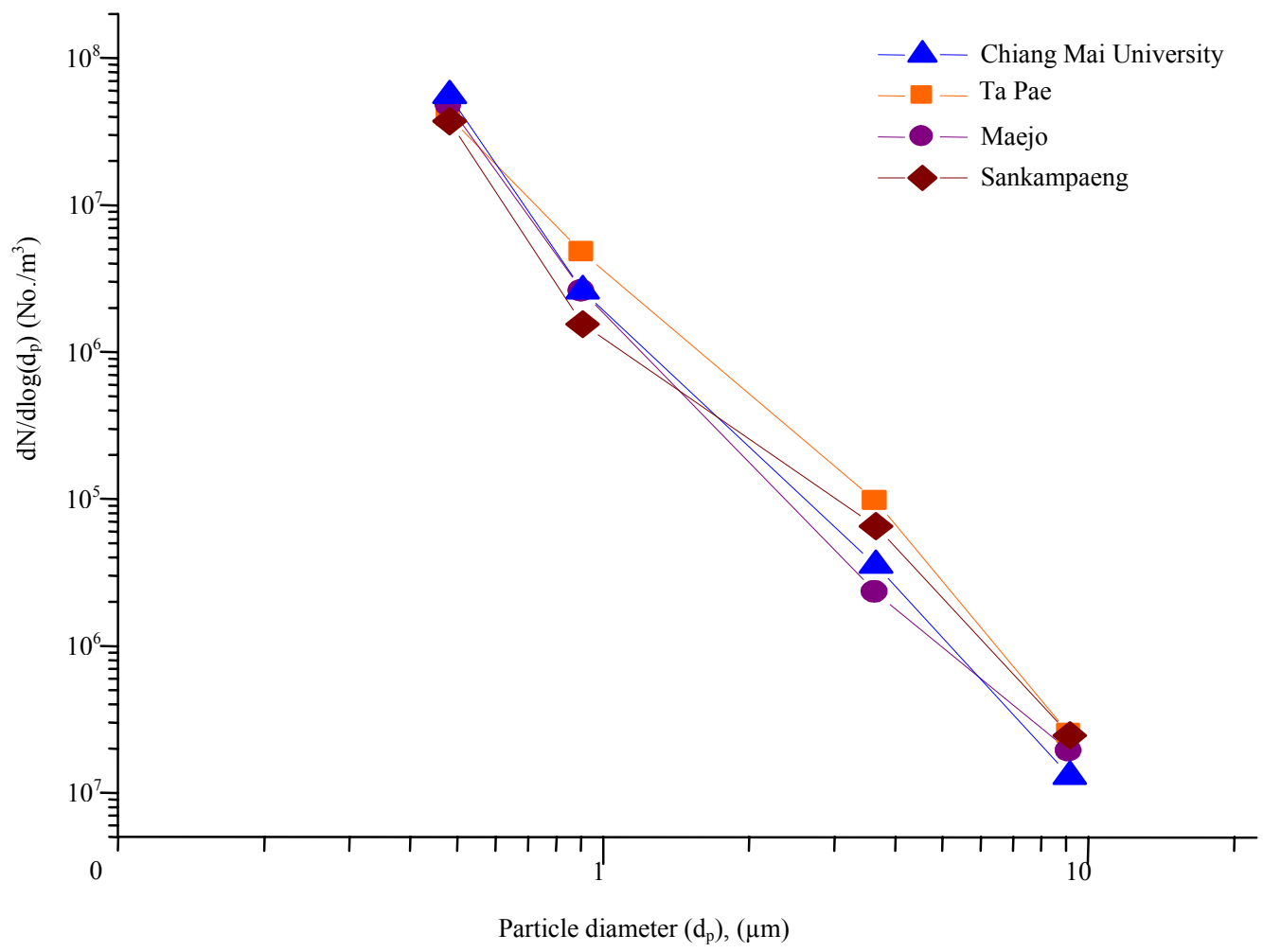

Fig. 4: Aerosol number size distribution at four different locations in Chiang Mai

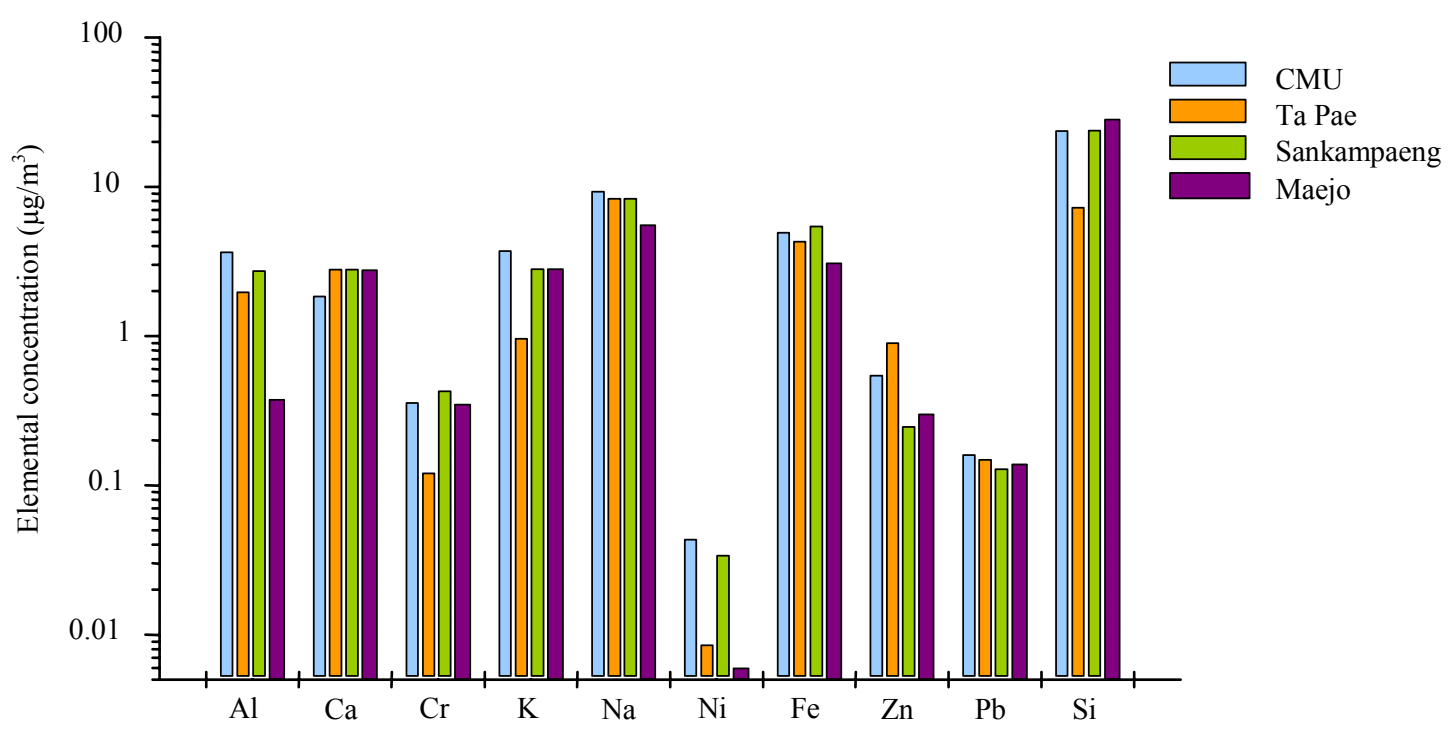

Fig. 5. Comparison of elemental concentration of PM from each site in Chiang Mai 
to be coming from biomass burning, consistent with reports of forest fires and open burning of vegetation in Chiang Mai during cool and dry season (Vinitketkumnuen, et al., 2002). For all sites, $\mathrm{Cr}$ and $\mathrm{Na}$ existed in very high concentration while $\mathrm{Ni}$ was detected in low level. High loading of Na element was not expected and the flame photometry method used in this study may have tendency to yield high Na. Nonetheless, a continental air mass movement might be able to transport marine aerosol for a far distance that eventually contributed to Na in Chiang Mai TSP. Concentrations of the elements $\mathrm{Pb}$ and $\mathrm{Zn}$ seem to be relatively high. It was unlikely that $\mathrm{Pb}$ was from the traffic because the leaded gasoline was phased out since 1995. It may likely be from the suspended road dust or local industries emitting $\mathrm{Pb}$. The source of $\mathrm{Pb}$ can not be identified conclusively. It was recommended that further study on this matter should be carried out.

\section{Principle component analysis}

PCA was used to identify possible sources of Chiang Mai PM. The Varimax-rotated PCA was applied to the elemental analysis data of particle samples combined from all sites across Chiang Mai. Results are presented in Table 2. For each principle component (PC), elements that were not strongly related to the particular PC appeared to have very small values which are not taken into account and are normally neglected. A total of three principle components which account for $83.9 \%$ of the total variance in the data set were obtained. The first PC accounted for $30.6 \%$ of the variance and was strongly associated with $\mathrm{Ni}$ and with $\mathrm{Al}, \mathrm{Ca}$ and $\mathrm{Na}$. Since $\mathrm{Al}, \mathrm{Ca}$ and $\mathrm{Na}$ represent crustal elements of earth origin and sea salt while Ni could be derived from fuel oil combustion as well as industrial combustion. This PC implied the long-term transportation of the mixture between industrial combustion exhaust and the soil dust. The second PC explained $27.6 \%$ of the variance and has high loadings for $\mathrm{Pb}, \mathrm{Fe}$ and $\mathrm{K}$. Pb exists in vehicular emissions, especially those of two-stroke engines such as motorcycle or scooter. Fe is detected in soil which may be contributed mainly from construction activities and traffic movement. $\mathrm{K}$ is believed to be emitted from biomass or vegetative burning such as open burning of wood, dried grass and other agricultural waste that normally occurs around the suburban area of the city. Particles resulting from vegetation burning are likely to cause visibility reduction and the perception of haziness (Morawska, et al., 1999) that envelops the city during cold and dry season here in Chiang Mai. Thus, the second PC represented the short-term transportation of the emission from 3 contributors: vehicular emissions, soil dust suspension and biomass or vegetative burning. The third PC was found to have high positive loading for $\mathrm{Si}$ and $\mathrm{Cr}$ and high negative loading for $\mathrm{Zn}$. It is generally known that $\mathrm{Si}$ is the second most abundant element and $\mathrm{Cr}$ could be contributed from both anthropogenic and natural sources while $\mathrm{Zn}$ represents tire wear origin. It can be said that this PC indicated the contrast influences between traffic-related sources and the other general sources.

\section{DISCUSSION AND CONCLUSION}

Daytime PM mass and number concentrations were measured at four locations in Chiang Mai during winter. The results showed that Chiang Mai has moderately high PM loading in its ambient air, nonetheless, air quality based on the aerosol particle concentration was below WHO guideline for total suspended PM. Results obtained for variation of size separated number concentrations in Chiang Mai illustrated similar spatial pattern and exhibited a decreasing trend throughout the day but did not vary markedly. The number concentrations appeared to be in similar order of magnitude between sampling sites, commercial, industrial, residential and rural. This is expected because it is generally accepted that particles below a few micron account for approximately $99 \%$ of the total number but for less than $50 \%$ of the total mass (Hinds, 1999). Change in mass concentration does not necessarily cause significant change in number concentration. PM samples were also collected and analyzed for their elemental composition. Data obtained were statistically analyzed by PCA method to identify possible sources of the ambient aerosol. Three principle components were found which accounted for more than $80 \%$ of the total variance. They suggested three groups of sources:

1) long distance sources such as sea spray, earth soil and industrial combustion, 2) short distance sources such as crustal re-suspension, vehicular related emissions and vegetation burning, and 3) the unknown distance sources with low influence of traffic emissions.

\section{ACKNOWLEDGEMENTS}

Financial support of this research project from the Thailand Research Fund is gratefully acknowledged. 


\section{REFERENCES}

Baek, S. O., Choi, J. S. and Hwang, S. M., (1997). A quantitative estimation of source contributions to the concentrations of atmospheric suspended particulate matter in urban, suburban, and industrial areas of Korea. Environ. Int., 23, 205-213.

Balachandran, S., Meena, B. R. and Khillare, P. S., (2000). Particle size distribution and its elemental composition in the ambient air of Delhi. Environ. Int., 26, 49-54.

Cheng, T., Lu, D., Chen, H. and Xu, Y., (2005). Physical characteristics of dust aerosol over Hunshan Dake sandland in Northern China. Atmos. Environ., 39, 1237-1243.

Chueinta, W., Hopkem, P. K. and Paatero, P., (2000). Investigation of sources of atmospheric aerosol at urban and suburban residential areas in Thailand by positive matrix factorization. Atmos. Environ., 34, 3319-3329.

Chun, Y., Kim, J., Choi, J. C., Boo, K. O., Oh, S. N. and Lee, M., (2001). Characteristic number size distribution of aerosol during Asian dust period in Korea. Atmos. Environ., 35, 2715-2721.

COMEAP., (1998). Quantification of the effects of air pollution on health in the United Kingdom. A Report by Committee on Medical Effects of Air Pollution to the Department of Health, Committee on Medical Effects of Air Pollution.UK, The Stationery Office, London.

Fung, Y. S. and Wong, L. W. Y., (1995). Apportionment of air pollution sources by receptor models in Hong Kong. Atmos. Environ., 29, 2041-2048.

Gomiscek, B., Hauck, H., Stopper, S. and Preining, O., (2004). Spatial and temporal variations of $\mathrm{PM}_{1}, \mathrm{PM}_{2.5}, \mathrm{PM}_{10}$ and particle number concentration during the AUPHEP-project. Atmos. Environ., 38, 3917-3934.

Gordon, G. E., (1988). Receptor models. Environ. Sci. Technol., 22, $1132-1142$.

Harrison, R. M., (1996). Pollution: causes, effects and control. Royal Society of Chemistry, Cambridge.

Harrison, R. M., Jones, M. R. and Collins, G., (1999). Measurements of the physical properties of particles in the urban atmosphere. Atmos. Environ., 33, 309-321.

HEI., (2002). Understanding the health effects of components of the particulate matter mix: progress and next steps. HEI Perspectives. April 2002, retrieved on January 2005, Health Effects Institutefrom http://www.healtheffects.org

Henry, R. C., Lewis, C. W., Hopke, P. K. and Williamson, H. J., (1984). Review of receptor model fundamentals. Atmos. Environ., 18, 1507-1515.

Hien, P. D., Binh, N. T., Truong, Y., Ngo, N. T. and Sieu, L. N., (2001). Comparative receptor modeling study of TSP, $\mathrm{PM}_{2}$, and $\mathrm{PM}_{2-10}$ in Ho Chi Minh City.Atmos. Environ., 35, 26692678.

Hinds, W. C., (1999). Aerosol technology: properties, behavior, and measurements of airborne particles. $2^{\text {nd. }}$ Eds. Wiley-Interscience, New York.

Kreyling, W. G., Tuch, T., Peters, A., Pitz, M., Heinrich, J., Stölzel, M., Cyrys, J., Heyder, J. and Wichmann, H. E., (2003). Diverging long-term trends in ambient urban particle mass and number concentrations associated with emission changes caused by the German unification. Atmos. Environ., 37, 3841-3848.

Laakso, L., Koponen, I. K., Monkkonen, P., Kulmala, M., Kerminen, V., Wehner, B., Wiedensohler, A., Wu, Z. and $\mathrm{Hu}$, M., (2006). Aerosol particles in the developing world; a comparison between New Delhi in India and Beijing in China. Water Air Soil Poll., 173, 5-20.

Lighty, J. S., Veranth, J. M. and Sarofim, A. F., (2000). Combustion aerosols: factors governing their size and composition and implications to human health. J. Air Was. Manag. Assoc., 50, 1565-1618.

Matsushita, H., Takahashi, Y., Amagai, T. and Koottatep, S., (1998). Polynuclear aromatic hydrocarbons in the roadside atmosphere in Chiang Mai, Thailand. J. Environ. Chem., 8, $63-70$.

Mönkkönen, P., Uma, R., Srinivasan, D., Koponen, I. K., Lehtinen, K. E. J., Hämeri, K., Suresh, R., Sharma, V. P. and Kulmala, M., (2004). Relationship and variations of aerosol number and $\mathrm{PM}_{10}$ mass concentrations in a highly polluted urban environment-New Delhi, India. Atmos. Environ., 38, 425-433

Morawska, L., Thomas, S., Jamriska, M. and Johnson, G., (1999). The modality of particle size distributions of environmental aerosols. Atmos. Environ., 33, 4401-4411.

Ostro, B., Chestnut, L., Vichitvadakan, N. and Laixuthai, A. (1999). The impact of particulate matter on daily mortality in Bangkok, Thailand. J. Air Was. Manag. Assoc., 49, 100107.

Panther, B. C., Hooper, M. A. and Tapper, N. J., (1999). A comparison of air particulate matter and associated polycyclic aromatic hydrocarbons in some tropical and temperate urban environments. Atmos. Environ., 33, 40874099.

Parekh, P. P., Khwaja, H. A., Khan, A. R., Naqvi, R. R., Malik, A., Shah, S. A., Khan, K. and Hussain, G., (2001). Ambient air quality of two metropolitan cities of Pakistan and its health implications. Atmos. Environ., 35, 5971-5978.

Pope, C. A., Dockery, D. W. and Schwartz, J. (1995). Review of epidemiological evidence of health effects of particulate air pollution. Inh. Toxic., 7, 1-18.

Qin, Y., Chan, C. K. and Chan, L. Y. (1997). Characteristics of chemical compositions of atmospheric aerosol in Hong Kong: spatial and seasonal distributions. Sci. Total Environ., 206, 25-37.

Salam, A., Bauer, H., Kassin, K., Ullah, S. M. and Puxbaum, H., (2003). Aerosol chemical characteristics of a mega-city in Southeast Asia (Dhaka-Bangladesh).Atmos. Environ., 37, 2517-2528.

Sharma, D. K., Rai, J., Israil, M. and Singh, P., (2003). Summer variations of the atmospheric aerosol number concentration over Roorkee, India. J. Atmos. Solar-Terrestrial Phy., 65, 1007-1019.

Trier, A., (1997). Submicron particles in an urban atmosphere: a study of optical size distributions-I. Atmos. Environ., 31, 909-914.

Vinitketkumnuen, U., Kalayanamitra, K., Chewonarin, T. and Kamens, R., (2002). Particulate matter, $\mathrm{PM}_{10}$ and $\mathrm{PM}_{2.5}$ levels, and airborne mutagenicity in Chiang Mai, Thailand. Mutat. Res., 519, 121-131. 


\section{AUTHOR(S) BIOSKETCHES}

Tippayawong, N., Ph.D., Graduated from Imperial College, UK, and is an assistant professor in the Department of Mechanical Engineering, Chiang Mai University, Thailand.

Email:nakorn@dome.eng.cmu.ac.th

Pengchai, P., Ph.D., Graduated from University of Tokyo, Japan, and is an assistant professor in the Department of Environmental Engineering, Chiang Mai University, Thailand.

Email:petch@eng.cmu.ac.th

Lee, A., Ph.D., Graduated from Stanford University, USA, and is a visiting professor in the Department of Mechanical Engineering, Chiang Mai University, Thailand.

Email:alee425@yahoo.com

\section{This article should be referenced as follows:}

Tippayawong, N., Pengchai, P. and Lee, A., (2006). Characterization of ambient aerosols in Northern Thailand and their probable sources. Int. J. Environ. Sci. Tech., 3 (4), 359-369 